\title{
Taxation and Inequality in Developing Countries: Lessons from the Recent Experience of Latin America
}

Journal Article

Author(s):

Martorano, Bruno

Publication date:

2018-03

Permanent link:

https://doi.org/10.3929/ethz-b-000250933

Rights / license:

Creative Commons Attribution-NonCommercial-ShareAlike 4.0 International

Originally published in:

Journal of International Development 30(2), https://doi.org/10.1002/jid.3350 


\title{
TAXATION AND INEQUALITY IN DEVELOPING COUNTRIES: LESSONS FROM THE RECENT EXPERIENCE OF LATIN AMERICA
}

\author{
BRUNO MARTORANO ${ }^{1,2 *}$ \\ ${ }^{1}$ Maastricht Graduate School of Governance/UNU-MERIT, Maastricht University, Maastricht, The \\ Netherlands \\ ${ }^{2}$ NADEL Center for Development and Cooperation, ETH Zurich, Zürich, Switzerland
}

\begin{abstract}
This paper aims to advance understanding about the relationship between taxation and inequality in developing countries, focusing on the recent experience of Latin America. Tax changes promoted equality since the early 2000s. In particular, the increasing contribution of direct taxes with respect to indirect taxes promoted the progressivity of the tax system and contributed to the reduction of inequality. Yet the effectiveness of taxation in promoting equality in Latin America is still limited by several factors such as the low average tax revenue, the inability to tax top incomes and the low contribution of taxes on property. (C) 2018 UNU-WIDER. Journal of International Development published by John Wiley \& Sons, Ltd.
\end{abstract}

Keywords: tax policy; inequality; redistribution; Latin America

JEL Classification: D31; D63; H20

\section{INTRODUCTION}

The role of tax policy and in particular its effectiveness to influence inequality in developing countries is one of the most debated topics in economics (Bird \& Zolt, 2005). Indeed, opposing views have dominated the discussion around the role of taxation in different periods influencing tax revenue and tax composition. Initially, taxation was believed to be a powerful policy tool that could be used to mobilize revenue (Musgrave, 1959) whereas progressive taxes were thought to be strategically important to favour a

*Correspondence to: Bruno Martorano, Maastricht Graduate School of Governance/UNU-MERIT, Maastricht University, Maastricht, The Netherlands; or NADEL Center for Development and Cooperation, ETH Zurich, Zürich, Switzerland.

E-mail: bruno.martorano82@gmail.com

() 2018 UNU-WIDER. Journal of International Development published by John Wiley \& Sons, Ltd. This is an open access article under the terms of the Creative Commons Attribution-NonCommercial-ShareAlike License, which permits use and distribution in any medium, provided the original work is properly cited, the use is non-commercial and the content is offered under identical terms. 
more inclusive process of economic development (Kaldor, 1963). Consequently, in the post-Second World War period, policymakers assigned to taxation the specific role of promoting redistribution through the introduction of high tax rates on income (Cornia, Gómez-Sabaíni, \& Martorano, 2011). Yet the arrival of the crisis in the early 1970s casts some doubts about the effectiveness of taxation on influencing income distribution and correcting market failures. In addition, there was a growing consensus that taxation could generate negative consequences in terms of growth affecting consumption and investment decisions (Feldstein, 2012). As a result, it had been suggested on multiple occasions that the only way to achieve effective results in terms of equality was through public expenditure (Bird \& Zolt, 2005). The strength of these ideas and their capacity to affect policy design was particularly evident in developing countries where the role of taxation to promote equality was believed, both conceptually and practically, to be more difficult owing to the presence of a large informal sector and the lack of proper administrative structures (Mahon, 2009).

Recently, taxation is back at the centre of the policy and research agenda (Duncan \& Sabirianova Peter, 2016). Indeed, while both developed and developing countries dramatically reduced tax rates, inequality has sharply increased during the last decades, generating outrage across the world. Some of the most prominent economists (e.g. Piketty, 2014; Atkinson, 2015) have resumed to propose taxation as a powerful solution to promote a more equal income distribution. While the majority of the existing research (and the relative policy discussion) focuses on developed countries, less attention is paid on the rest of the world.

This work contributes to fill this gap analysing the redistributive role of tax policy in Latin America. This region represents an emblematic case study for several reasons. The level of taxation has been historically lower in Latin America than in other regions. The inability to promote the development of a proper tax system was due to the strong relationship between wealth and political power, which was inherited from the colonial period (Edwards, Esquivel, \& Márquez, 2007). In addition, in this region more than in others, tax policy design has suffered from the influence of the aforementioned alternative views. In particular, Latin America was heavily influenced by advice from the Washington Consensus that promotes the view that the tax system should assure efficiency and horizontal equity, whereas taxation was considered ineffective in terms of redistribution (Bird \& Zolt, 2005). Nonetheless, since the early 2000s, social and political factors have called for more attention on the progressivity design of tax policy. As a result, Latin America has recorded a sizeable increase in tax revenue driven mainly by a rise in direct taxation. Over the same period, the region has experienced significant results in terms of inequality reduction (Cornia, 2014).

Along these lines, the aim of this paper is to investigate empirically whether the recent changes in the level and composition of taxation observed in the region have contributed to the reduction of inequality recorded in the majority of the Latin American countries during the last decade. The analysis uses a longitudinal data set compiled across 18 Latin American countries over the period 1990-2015. The results show that the impact of taxation is not neutral. In particular, the increasing contribution of direct taxes contributed to the decline of inequality since the 2000s. This paper contributes to the existing literature in a variety of ways. First, it contributes to the interesting and rich literature reporting evidence on the impact of taxation on inequality. Although the majority of works focuses on advanced economies (Atkinson \& Leigh, 2010) or uses a large number of countries for a long period of time (Martínez-Vázquez, Vulovic, \& Moreno-Dodson, 2012; Duncan \& Sabirianova Peter, 2016), only few studies have tried to investigate 
the contribution of taxation to the recent decline of inequality in Latin America. While most of the existing works related to this region tend to be country-specific incidence studies that rely on micro-simulation exercises (such as the contributions related to the Commitment to Equity project ${ }^{1}$ ), in my knowledge, there are only two papers close to the present work: Cornia et al. (2011) and Tsounta and Osueke (2014). Similar to them, this paper investigates the contribution of tax changes on the recent decline of inequality, but contrary to these papers, the specific contribution of different types of taxes is disentangled, providing further evidence on this issue. Furthermore, the impact of taxation on different parts of the distribution is tested. Whereas the previous analyses focus on Gini coefficient, here the impact of taxation on other indicators of inequality, such as the Palma index as well as the 95/50, the 95/80 and the 90/10 percentile ratios, is also tested. Finally, this paper contributes to the political economy literature providing useful lessons and policy implications for other middle-income countries. Indeed, the understanding of the role of taxation in promoting equality is becoming increasingly important given the need to promote a more inclusive process of economic development in context of high levels of inequality such as Latin America or rising level of disparities such as other developing regions.

\section{INEQUALITY AND TAXATION IN LATIN AMERICA ${ }^{2}$}

\subsection{Inequality Evolution and Tax Changes during the Last Decades}

Inequality in Latin America has been historically high given an institutional structure inherited from the colonial period, which promoted the interests of a small elite and perpetuated disparities through the time (Engerman \& Sokoloff, 2005). The dependency from external conditions, the frequent financial crises and neoliberal policies adopted since the mid-1970s provoked a further increase of inequality that reached its peak value in 2002 (Cornia, 2014). Yet inequality started to decline in the early 2000s (López-Calva \& Lustig, 2010; Cornia, 2014; Cord et al., 2016). Between 2002 and 2015, Gini decreased by 8 points (from 54 to 46 points) achieving a value lower than the average recorded in the pre-Washington consensus period (Figure 1). Different factors have been advanced to explain this unexpected result such as economic growth in the mid-2000s (World Bank, 2011) and the improvement in external conditions (Székely \& Mendoza, 2015).

Despite these, Cornia et al. (2011) note that the contribution of taxation is also a significant aspect (and often ignored) behind the recent and extraordinary performance of Latin America. Indeed, inequality started to decrease when tax revenue steadily increased. In particular, the ratio of tax revenue on gross domestic product (tax/GDP) increased by 3 points over the period 2002-2008 (Figure 1). The arrival of the Great Recession affected economic conditions of the region and provoked a decline in the tax/GDP ratio by around 1 point. However, the tax/GDP ratio recovered the upward trend and kept on increasing by 2 points up to 17 per cent (Figure 1). Of course, there are important differences in terms of the magnitude of observed changes as well as a

\footnotetext{
${ }^{1}$ http://www.commitmentoequity.org/

${ }^{2}$ For a detailed description of tax changes implemented in Latin American countries over the last decades, see Gómez-Sabaíni et al. (2016).
} 


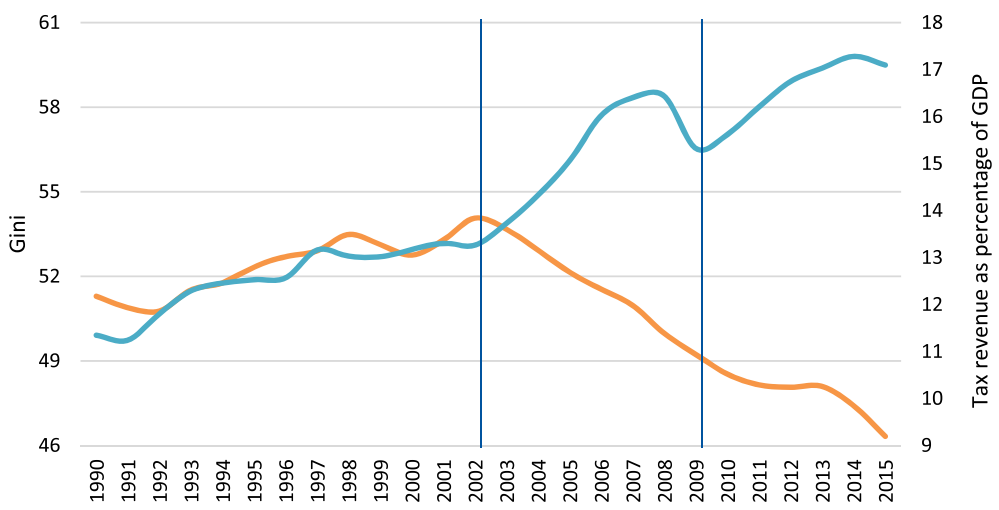

Gini Tax/GDP ratio excluding social contributions

Source: Inequality data are extracted from the IDLA Dataset that have been updated using information from the Socio-Economic Database for Latin America and the Caribbean; the tax/GDP ratio is from the GRD 2017.

Figure 1. Gini coefficient and tax revenue in 18 Latin American countries, 1990-2015. GDP, gross domestic product; GRD, Government Revenue Dataset; IDLA, Income Distribution in Latin America. [Colour figure can be viewed at wileyonlinelibrary.com]

substantial heterogeneity in the level of the tax/GDP ratio across countries. Over the period 2002-2015, tax revenue sharply increased in Argentina (by 9 points) and especially in Bolivia (by 15 points). On the other hand, the tax/GDP ratio remained stable in Costa Rica, the Dominican Republic, and decreased by nearly 2 points in Guatemala. Looking at the level of the tax/GDP ratio, Argentina and Bolivia together with Brazil reported the highest levels of tax revenue on GDP around 2015. In particular, the tax/GDP ratio grew up to 31 per cent in Bolivia, whereas it was close to 26 per cent in Brazil and 24 per cent in Argentina.

Yet the recent changes in tax revenue level are not enough to explain the evolution of inequality during the last decade. Indeed, Figure 1 shows that tax revenue increased in the 1990s and in the 2000s whereas inequality decreased only after 2002. However, a more detailed analysis shows a fundamental difference between these two periods related to changes in tax composition. In particular, the increase in tax revenue in the 1990s was mainly driven by the rise in taxes on sales and more specifically by the notable growth recorded by VAT. Table 1 shows that the relative contribution of taxes on sales increased

Table 1. Tax composition in 1990, 2002 and 2015

\begin{tabular}{lcccc}
\hline & $\begin{array}{c}\text { Taxes on income, profits } \\
\text { and capital gains }\end{array}$ & $\begin{array}{c}\text { Taxes on } \\
\text { property }\end{array}$ & $\begin{array}{c}\text { Taxes on } \\
\text { sales }\end{array}$ & $\begin{array}{c}\text { Other } \\
\text { taxes }\end{array}$ \\
\hline 1990 & 28 & 3 & 33 & 34 \\
2002 & 26 & 3 & 41 & 28 \\
2015 & 33 & 2 & 39 & 25 \\
Variation for 1990-2002 & -2 & 0 & 8 & -6 \\
Variation for 2002-2015 & +7 & -1 & -2 & -3 \\
\hline
\end{tabular}

Source: Author's elaboration on the Government Revenue Dataset 2017. 
by 8 points between 1990 and 2002. In contrast, the relative contribution of taxes on income, profits and capital gains decreased by 2 points whereas that of other taxes (e.g. taxes on international trade) fell by around 6 points (Table 1). The scenario changed completely in the following decade in which inequality decreased. In particular, the growth recorded in tax revenue was mainly driven by the extraordinary performance recorded by taxes on income, profits and capital gains. Notably, the average contribution of these taxes to the average tax revenue increased by 7 points between 2002 and 2015 (Table 1). However, despite these progresses, the contribution of taxes on personal income was still low and around 1.6 per cent of GDP in 2015. On the other hand, the contribution of other taxes decreased (Table 1).

\subsection{Factors Promoting Tax Changes in the 2000s}

Tax changes in the 2000s were promoted by many factors. First, the positive economic performance in the 2000s contributed to generate more and better jobs, a new middle class that in turn promoted an expansion of the tax base (Bird \& Zolt, 2013). Second, over the same period, the positive evolution of external conditions heavily influenced Latin American economies (Fricke \& Süssmuth, 2014). In particular, the revenue capacity of countries exporting oil and non-oil commodities was affected by the changes in international markets, particularly by the increase of commodity prices and the demand of primary products. Some countries (i.e. Argentina, Bolivia, Chile and Venezuela) implemented explicit measures in order to take advantages of these conditions (Gómez-Sabaíni \& Morán, 2014). ${ }^{3}$ Third, Latin American governments kept on introducing more pragmatic policies that take into account the country's characteristics. Among the most interesting examples of heterodox forms of taxation were the implementation of simplified or presumptive system of taxation developed to improve taxation on small taxpayers as well as the introduction of taxes on financial transactions (Cornia et al., 2011; Gómez-Sabaíni, Martorano, \& Morán, 2016).

Finally, the new left governments elected in the early 2000s implemented explicit measures to strengthen tax mobilization and the redistributive capacity of their tax systems. Consistent with the reforms in the 1990s, most countries kept on expanding their income tax base introducing significant measures to cover both labour and capital income (ECLAC, 2013). In contrast to the tax reforms implemented in the 1980s and 1990s, some South American countries also increased tax rates or introduced new ones (ECLAC, 2013). For example, the Ecuador government introduced a tax reform in 2008 aiming explicitly at increasing the progressivity of personal income tax and, therefore, equality. In addition, a number of countries introduced a dual tax system reform following the experience of Scandinavian countries. For example, the 2007 Uruguayan tax reform introduced a progressive taxation on labour income consisting of six rates ranging from 0 to 25 per cent and a flat rate on capital income of 12 per cent (Martorano, 2014). In addition, in 2012, the top rate of personal income tax was further increased to 30 per cent. In 2009, Peru implemented a similar tax reform introducing a progressive taxation on labour income with rates ranging from 0 to 30 per cent, with a tax rate of 6.25 per cent on 80 per cent of capital income. More recently, other countries such as Chile, Colombia and Mexico introduced tax reforms by increasing tax rates and by cutting exemptions (ECLAC, 2015).

\footnotetext{
${ }^{3}$ More information is reported in Gómez-Sabaíni and Morán (2014).
} 


\subsection{Impact of the Recent Tax Changes on Inequality}

The relationship between taxation and inequality in Latin American countries has been studied for a long time. The vast majority of analyses conclude that taxation has a modest (and sometimes regressive) impact on income distribution. According to Goñi, Lopéz, and Servén (2011), this is because of the neutral profile of the tax system and the poor performance in collecting revenue. However, as explained earlier, only few studies have tried to investigate whether and how the recent tax changes have contributed to the recent decline of inequality in Latin American countries. For example, Tsounta and Osueke (2014) show that higher tax revenue is associated with more equality. Cornia et al. (2011) report that the greater reliance on direct taxes during the recent decade has significantly contributed to the reduction of inequality on average by $0.4-0.8$ points.

Although there are few results based on regression methods, there is a growing and recent tax incidence literature confirming that changes in tax level and composition have generated important consequences in terms of progressivity and redistributivity (Gómez-Sabaíni et al., 2016). This is particularly evident in South America (ECLAC, 2015). For example, Martorano (2014) shows that the 2007 tax reform in Uruguay (and in particular changes on labour income taxation and social contributions) generated a positive impact on equity without impairing efficiency. ${ }^{4}$ Cruces and Gasparini (2008) and Rossignolo (2016) point out that the redistributive capacity of the Argentinian tax system has increased since the early 2000s. In contrast, tax systems still show a modest capacity to redistribute in the Andean, Central American and Caribbean countries. Cano (2015) reports that personal income taxation is highly progressive in Ecuador but its ability to redistribute is low because rich people still benefit from many legal tax deductions that affect their taxable income. Aristy-Escuder, Cabrera, Moreno-Dodson, and Sánchez-Martín (2016) show that tax system in the Dominican Republic shows a good level of progressivity and redistributivity even though exemptions and tax evasion result in a low share of direct taxes to GDP. Despite the progress with respect to the past, the redistributivity incidence of taxation in Honduras and Nicaragua is not significant considering that the Reynolds-Smolensky index is close to zero (Cornia et al., 2011). Similarly, the tax system in Bolivia, El Salvador and Guatemala is slightly progressive or neutral considering the impact of direct taxes (ECLAC and IEF, 2014; ICEFI, $2017 \mathrm{a}, \mathrm{b})$. Lastly, the share of income paid by the wealthiest 10 per cent of the population to the government in taxes is still low in almost all countries even though it is increasing in recent years (ECLAC, 2016).

Overall, the progressivity and redistributivity capacity of the tax system in Latin American countries is still modest (Lustig, 2016) even though important progresses have been recorded with respect to the past (Cornia et al., 2011).

\section{REGRESSION ANALYSIS}

\subsection{Empirical Framework}

Whether changes in taxation promoted the recent reduction of inequality remains an open question. Although the previous results on tax incidence provide some interesting

\footnotetext{
${ }^{4}$ Burdín, Esponda, and Vigorito (2014) confirm that the reform contributes to reducing inequality by 2 Gini points.
} 
information on the redistributive effect of tax systems, they do not reveal a lot in terms of causality about the specific contribution of taxation on the evolution of income distribution in Latin America over the last two decades. This work aims to fill this gap providing new evidence as well as disentangling the specific contribution of different kinds of taxes on inequality and showing the impact of taxation on different parts of the distribution. In doing so, information has been collected for 18 Latin American countries over the period 1990-2015. The following baseline model is estimated:

$$
\operatorname{Gini}_{i t}=\alpha_{0}+\alpha_{1} \operatorname{Tax} / \mathrm{GDP}_{i t}+\alpha_{2} Z_{i t}+u_{i t}, \quad i=1,2, \ldots, N ; t=1,2, \ldots, T
$$

where $i$ and $t$ identify country and year and $u_{i t}$ defines the idiosyncratic error term, respectively.

The dependent variable refers to inequality on disposable income, and it is extracted from the Income Distribution in Latin America data set (Martorano \& Cornia, 2011). The original data have been updated using information from the Socio-Economic Database for Latin America and the Caribbean (CEDLAS and World Bank, n.d.).

Taxation data are extracted from the 2017 edition of the ICTD/UNU-WIDER Government Revenue Dataset (GRD), which provides comparable information aiming to overcome some of the weaknesses related to other existing sources (Prichard, Cobham, \& Goodall, 2014). For example, the GRD data set provides disaggregated information that helps to analyse in more details the impact of changes on tax composition on income inequality. In particular, this data set distinguishes between direct and indirect taxes. The former group includes (i) taxes on income, profits and capital gains and (ii) property taxes. The latter includes (i) taxes on good and services, (ii) taxes on international trade and (iii) other indirect taxes. ${ }^{5}$ Furthermore, the GRD data set provides a tax classification both inclusive and exclusive of natural resource revenue and social contributions. Therefore, the tax/GDP ratio included in the econometric model takes into account resources but excludes social contributions. The reason is because natural resource revenue may have played an important role for some countries (especially in the 2000s). By contrast, the exclusion of social contributions is related to the fact that 'these represent premia paid for an insurance contract whose public or private arrangements vary from country to country' (Cornia et al., 2011: 31).

Beyond this, $Z$ identifies a set of variables included in the econometric model to control for a number of economic factors that may have affected the evolution of inequality in Latin America over the period being considered. The first factor is the GDP per capita, which is expected ex ante to have a negative sign. Indeed, in developing countries, an economic boom tends to promote labour absorption and (under certain conditions) to increase wages, which in turn will have positive distributive consequences (Cornia \& Martorano, 2012). To proxy macroeconomic policies, the real effective exchange rate is included. The adoption of a stable and competitive exchange rate regime is expected to promote economic equality increasing the demand for unskilled workers and promoting economic stability (Helleiner, 2011). The third factor is the share of the debt on GDP, which is expected ex ante to have a positive sign in a context such as Latin America that was historically affected by debt crises with important distributional consequences (Cornia \& Martorano, 2012).

An additional factor of interest is the index of the terms of trade that gives rise to the possibility of understanding the extent to which income distribution was affected by

\footnotetext{
${ }^{5}$ The GRD tax classification is reported in Figure S1.
} 
changes in external conditions. The idea is that favourable external conditions may increase revenue and promote economic conditions, which in turn may have positive distributional consequences (Lustig, 2013). Foreign direct investment is an additional control that is expected to be equalizing when it promotes the demand for low-skilled or semi-skilled labour (Cornia \& Martorano, 2012). The sixth factor is the ratio of social spending on GDP that includes both spending on social assistance and on social security. This generates some uncertainty above the expected sign. While the effect of social assistance is expected to be redistributive, social security may contribute to increase inequality especially in countries with a large informal sector (Cornia et al., 2011). Finally, the supply of educated workers is proxied by the variation in the years of education among the working age population. It is expected that more education contributes to reducing inequality, thus buffering the pressure from market forces (Cornia \& Martorano, 2012). However, more years of education may lead to opposite results if education returns are convex (Battistón, García-Domench, \& Gasparini, 2014).

The description of the variables included in the regressions as well as their summary statistics and correlations is reported in Tables S1-S3.

\subsection{Regression Results}

In order to test the model in this study, first, I use a least squares dummy variable estimator. Model 1 in Table 2 shows that the tax/GDP ratio coefficient is not statistically significant. Yet it does turn statistically significant after the inclusion of country fixed effects-which are important to capture structural differences across countries. The coefficient is also negative and statistically significant after the inclusion of additional controls confirming the results of Tsounta and Osueke (2014). As expected, changes in inequality can be explained by the good economic performance and the improvements in external conditions, as reported in previous studies (World Bank, 2011; Székely \& Mendoza, 2015). Moreover, the regression analysis confirms that the recent improvements in debt management promoted equality in the region (Cornia \& Martorano, 2012). Lastly, Table 2 shows that the coefficients of foreign direct investment and social spending are positive and statistically significant. The former result may be explained by the fact that these investments were mainly concentrated in the natural resources and tertiary sectors. The latter may be explained by the fact that the share of social assistance on social spending was historically low in the region. By contrast, social security and especially pensions were regressive, especially in the 1990s, because of the high share of the informal sector and the reforms implemented during the Washington Consensus period (Cornia, 2014).

Yet it is possible that the aforementioned results are still inefficient. In their seminal contribution, Meltzer and Richard (1981) argue that high inequality could influence voters' preferences resulting in higher demands for redistribution. On the other hand, it is also possible that rising inequality leads to less support towards taxation (Epple \& Romano, 1996). Both cases highlight problems of reverse causality. To overcome these biases, Lee and Gordon (2005) instrument personal and corporate tax rates using the weighted average personal and corporate tax rates in other countries considering the inverse of the distance between the two countries. Recently, Duncan and Sabirianova Peter (2016) exploit the spatial correlation in tax rates among neighbouring countries to instrument for their measure of structural tax progressivity. In this paper, I use a similar empirical strategy regressing the tax/GDP ratio on the average value of the tax/GDP ratio in 
Table 2. Regression results, taxation and inequality in Latin American countries

\begin{tabular}{|c|c|c|c|c|c|c|}
\hline & LSDV & LSDV & LSDV & LSDV & LSDV & $\begin{array}{c}\text { IV- } \\
\text { Baseline }\end{array}$ \\
\hline Tax/GDP & $\begin{array}{c}0.008 \\
{[0.055]}\end{array}$ & $\begin{array}{c}-0.378 * * * \\
{[0.074]}\end{array}$ & $\begin{array}{c}-0.393 * * * \\
{[0.075]}\end{array}$ & $\begin{array}{c}-0.325 * * * \\
{[0.068]}\end{array}$ & $\begin{array}{c}-0.476 * * * \\
{[0.068]}\end{array}$ & $\begin{array}{c}-0.844 * * * \\
{[0.155]}\end{array}$ \\
\hline GDP per capita & $\begin{array}{c}-0.518 * * * \\
{[0.062]}\end{array}$ & $\begin{array}{c}-0.688 * * * \\
{[0.100]}\end{array}$ & $\begin{array}{c}-0.615 * * * \\
{[0.104]}\end{array}$ & $\begin{array}{c}-0.802 * * * \\
{[0.123]}\end{array}$ & $\begin{array}{c}-0.605 * * * \\
{[0.129]}\end{array}$ & $\begin{array}{c}-0.380 * * \\
{[0.156]}\end{array}$ \\
\hline REER & & & $\begin{array}{c}-0.016^{* *} \\
{[0.007]}\end{array}$ & $\begin{array}{c}-0.012 * \\
{[0.006]}\end{array}$ & $\begin{array}{c}-0.008 \\
{[0.007]}\end{array}$ & $\begin{array}{l}-0.018 * * \\
{[0.008]}\end{array}$ \\
\hline Debt/GDP & & & & $\begin{array}{l}0.044 * * * \\
{[0.006]}\end{array}$ & $\begin{array}{l}0.044 * * * \\
{[0.008]}\end{array}$ & $\begin{array}{l}0.028 * * * \\
{[0.009]}\end{array}$ \\
\hline Terms of trade & & & & $\begin{array}{c}-0.006 \\
{[0.006]}\end{array}$ & $\begin{array}{r}-0.013 * \\
{[0.007]}\end{array}$ & $\begin{array}{c}-0.004 \\
{[0.007]}\end{array}$ \\
\hline FDIs & & & & $\begin{array}{l}0.353 * * * \\
{[0.072]}\end{array}$ & $\begin{array}{l}0.228 * * * \\
{[0.077]}\end{array}$ & $\begin{array}{l}0.179 * * \\
{[0.081]}\end{array}$ \\
\hline $\begin{array}{l}\text { Public social } \\
\text { spending }\end{array}$ & & & & & $\begin{array}{c}0.168 * \\
{[0.086]}\end{array}$ & $\begin{array}{l}0.199 * * \\
{[0.094]}\end{array}$ \\
\hline $\begin{array}{l}\text { Variation of years of } \\
\text { education }\end{array}$ & & & & & $\begin{array}{c}1.127 \\
{[0.788]}\end{array}$ & $\begin{array}{c}1.485 \\
{[1.050]}\end{array}$ \\
\hline Constant & $\begin{array}{l}54.050 * * * \\
{[0.738]}\end{array}$ & $\begin{array}{l}63.095^{* * *} * \\
{[1.943]}\end{array}$ & $\begin{array}{l}65.228 * * * \\
{[2.255]}\end{array}$ & $\begin{array}{l}60.491 * * * \\
{[2.235]}\end{array}$ & $\begin{array}{l}59.119^{* * *} \\
{[1.629]}\end{array}$ & $\begin{array}{l}61.981 * * * \\
{[2.032]}\end{array}$ \\
\hline Country dummies & no & yes & yes & yes & yes & yes \\
\hline Observations & 443 & 443 & 443 & 424 & 339 & 339 \\
\hline$R$-squared & 0.137 & 0.703 & 0.707 & 0.735 & 0.778 & 0.755 \\
\hline Endogeneity test & & & & & & 0.002 \\
\hline
\end{tabular}

Source: Author's compilation.

$* * * P<0.01$.

$* * P<0.05$.

$* P<0.1$.

Robust standard errors in brackets.

FDI, foreign direct investment; GDP, gross domestic product; LSDV, least squares dummy variable estimator; REER, real effective exchange rate.

countries within the same sub-region. ${ }^{6}$ The choice of this instrument is also explained by the significance of fiscal spill-over effects in policy design across Latin America (Cornia et al., 2011). Indeed, governments are more likely to reform their tax system if neighbouring countries and countries with similar economic and institutional setting do the same. For example, VAT was first introduced in Brazil (1967) and shortly afterward in all other countries. Under the aegis of the 'Washington Consensus', taxes on international trade and on personal income were decreased. The recent dual tax reform implemented in Uruguay is influencing tax design in other Latin American countries.

First stage results are reported in Table S4. The results confirm that the instrument is strongly correlated with the share of taxes on GDP. In addition, the Kleibergen-Paap Wald F statistic is around 57 while the Cragg-Donald F statistic is around 110 and higher than the Stock and Yogo critical values rejecting the null hypothesis that the instrument is weak. In addition, the endogeneity test rejects the null hypothesis confirming that the main estimator (the tax/GDP ratio) may be considered endogenous. Table 2 shows the IV estimate in column 6 . The coefficient of the tax/GDP ratio is still negative and statistically

\footnotetext{
${ }^{6}$ Sub-regions considered in this paper are the Andean region (Bolivia, Colombia, Ecuador, Peru and Venezuela); Central America and the Caribbean (Costa Rica, the Dominican Republic, El Salvador, Honduras, Mexico, Nicaragua and Panama); and Southern Cone (Argentina, Brazil, Chile, Paraguay and Uruguay).
} 
significant. In particular, an increase of 1 point in the tax/GDP ratio would reduce the Gini coefficient by 0.8 points. The results related to the other variables are similar to the least squares dummy variable estimates with the only exception of the real effective exchange rate and terms of trade coefficient. While the latter is no longer statistically significant, the real effective exchange rate coefficient is negative and statistically significant confirming that the adoption of a stable and competitive exchange rate regime may contribute to reduce inequality. For the rest of the paper, IV estimate will be considered as the baseline model.

In order to check the validity of the previous results, I implement a number of robustness tests. First, I use alternative instruments such as the average value of the tax/GDP ratio in the previous 2, 3 and 5 years in the three sub-regions and the average value of the tax/GDP ratio in countries sharing the same borders (similarly to Duncan \& Sabirianova Peter, 2016). Second, I use alternative estimators such as the Lewbel's method (Lewbel, 2012), the 'difference GMM' (Arellano \& Bond, 1991) and the 'system GMM' estimator (Blundell \& Bond, 1998). Third, I test the validity of the regression results using alternative tax definitions (excluding/including the resource component and social contributions). In all cases, the main estimator is negative and statistically significant confirming the redistributive role of taxation in Latin America. Results and detailed information on these tests are reported in Tables S5-S8.

\section{TAX CHANGES AND DISTRIBUTIONAL EFFECTS}

Section 2.1 argues that taxation contributed to the reduction of inequality only in the 2000s, thanks to the changes in tax composition and in particular to the increasing contribution of direct taxes. Yet the effectiveness of taxation in promoting equality may still be limited by several factors such as the inability to tax top incomes. This section further tests these hypotheses.

\subsection{Taxation and Inequality: 1990s versus 2000s}

In this section, the initial hypothesis is tested: whether taxation was effective in promoting equality only in the last decade. In doing so, the previous model specification is replicated splitting the sample period in two sub-periods, that is, 1990-2001 and 2002-2015. ${ }^{7}$ Table 3 (column 3) shows that the coefficient of the tax/GDP ratio is not statistically significant considering the period 1990-2001. In contrast, the results reported in column 4 are similar to those reported in the baseline model. Some interesting difference is related to the size of the tax/GDP ratio coefficient. Indeed, increasing the tax/GDP ratio by 1 point would result in reducing inequality by more than 1.3 points in the 2000 s.

Some of the controls also generate some interesting results. Table 3 shows that economic growth promoted equality only in the last period. This is in line with the results presented in the previous literature (Cornia, 2014). Moreover, as expected, the high debt level and the related economic instability and austerity process increased inequality in the 1990s. Table 3 also confirms that foreign direct investments were un-equalizing in

\footnotetext{
${ }^{7}$ Also the Chow rejects the null hypothesis of stable coefficients (Prob $>F=0.0002$ ) confirming the idea that these two sub-periods are different.
} 
Table 3. Regression results, taxation and inequality in Latin American countries-different periods

\begin{tabular}{lccc}
\hline & IV-Baseline & $1990-2001$ & $2002-2015$ \\
\hline Tax/GDP & $-0.844^{* * *}$ & -0.460 & $-1.343^{* * *}$ \\
& {$[0.155]$} & {$[0.590]$} & {$[0.371]$} \\
GDP per capita & $-0.380^{* *}$ & 0.396 & $-0.629^{* * *}$ \\
& {$[0.156]$} & {$[0.342]$} & {$[0.219]$} \\
REER & $-0.018^{* *}$ & 0.022 & -0.017 \\
& {$[0.008]$} & {$[0.017]$} & {$[0.015]$} \\
Debt/GDP & $0.028^{* * *}$ & $0.091^{* * *}$ & -0.019 \\
& {$[0.009]$} & {$[0.025]$} & {$[0.027]$} \\
Terms of trade & -0.004 & 0.019 & 0.005 \\
& {$[0.007]$} & {$[0.023]$} & {$[0.013]$} \\
FDIs & $0.179^{* *}$ & $0.205^{* * *}$ & 0.041 \\
& {$[0.081]$} & {$[0.076]$} & {$[0.127]$} \\
Public social spending & $0.199^{* *}$ & -0.009 & $-0.675^{* *}$ \\
& {$[0.094]$} & {$[0.062]$} & {$[0.274]$} \\
Variation of years of education & 1.485 & $2.048^{* * *}$ & -0.327 \\
& {$[1.050]$} & {$[1.042]$} & {$[1.483]$} \\
Constant & $61.981^{* * *}$ & $40.003^{* * *}$ & $73.843^{* * *}$ \\
& {$[2.032]$} & {$[5.632]$} & {$[5.689]$} \\
Country dummies & yes & yes & yes \\
Observations & 339 & 123 & 216 \\
$R$-squared & 0.755 & 0.922 & 0.752 \\
Endogeneity test & 0.002 & $n . d$ & 0.024 \\
\hline
\end{tabular}

Source: Author's compilation.

$* * * P<0.01$.

$* * P<0.05$.

$* P<0.1$.

Robust standard errors in brackets.

FDI, foreign direct investment; GDP, gross domestic product; REER, real effective exchange rate.

the 1990s because they were mainly concentrated in the primary and tertiary sectors. The education coefficient is positive in the 1990s while it is no longer statistically significant in the 2000s. This may be explained by changes in education returns in the labour market. Finally, social spending promoted equality in the last years. This result may be related to the growing role of social assistance and the rapid expansions of antipoverty and conditional cash transfers programmes (Gómez-Sabaíní et al., 2016).

Overall, these results confirm that the recent policy changes have promoted the progressivity and redistributivity of taxation in Latin America while taxation was mainly neutral in the 1990s.

\subsection{Tax Changes}

This section tests whether the results presented previously were mainly driven by changes in tax composition. ${ }^{8}$ In particular, the growing role of direct taxes would promote tax progressivity implying that the wealthiest deciles contribute more in tax payment compared with the poorest deciles and therefore disposable income would be

\footnotetext{
${ }^{8}$ The main instrument is replaced using the sub-regional value of the main tax indicators considered in the analysis. However, instruments are weak in the case of models 3 and 5.
} 
Table 4. Regression results, taxation and inequality in Latin American countries

\begin{tabular}{|c|c|c|c|c|c|}
\hline & $\begin{array}{c}\text { IV- } \\
\text { Baseline }\end{array}$ & Model 2 & Model 3 & Model 4 & Model 5 \\
\hline Tax/GDP & $\begin{array}{c}-0.844 * * * \\
{[0.155]}\end{array}$ & & & & \\
\hline Direct taxes/GDP & & $\begin{array}{l}-2.802 * * * \\
{[0.548]}\end{array}$ & & & \\
\hline Direct taxes on indirect taxes & & & $\begin{array}{l}-0.820 * * \\
{[0.355]}\end{array}$ & & \\
\hline Direct taxes on total tax revenue & & & & $\begin{array}{l}-1.070 * * * \\
{[0.248]}\end{array}$ & \\
\hline $\begin{array}{l}\text { Taxes on income, profits and capital } \\
\text { gains as share of total tax revenue }\end{array}$ & & & & & $\begin{array}{r}-1.864 * \\
{[1.123]}\end{array}$ \\
\hline $\begin{array}{l}\text { Taxes on property as share of total tax } \\
\text { revenue }\end{array}$ & & & & & $\begin{array}{r}-6.587 \\
{[9.530]}\end{array}$ \\
\hline GDP per capita & $\begin{array}{c}-0.380 * * \\
{[0.156]}\end{array}$ & $\begin{array}{c}0.519 \\
{[0.336]}\end{array}$ & $\begin{array}{c}3.342 * \\
{[2.029]}\end{array}$ & $\begin{array}{l}1.513^{* * *} \\
{[0.653]}\end{array}$ & $\begin{array}{c}3.890 \\
{[3.324]}\end{array}$ \\
\hline REER & $\begin{array}{c}-0.018 * * \\
{[0.008]}\end{array}$ & $\begin{array}{c}-0.007 \\
{[0.011]}\end{array}$ & $\begin{array}{c}-0.015 \\
{[0.034]}\end{array}$ & $\begin{array}{c}0.007 \\
{[0.016]}\end{array}$ & $\begin{array}{c}0.051 \\
{[0.078]}\end{array}$ \\
\hline Debt/GDP & $\begin{array}{l}0.028 * * * \\
{[0.009]}\end{array}$ & $\begin{array}{c}0.016 \\
{[0.014]}\end{array}$ & $\begin{array}{c}0.030 \\
{[0.037]}\end{array}$ & $\begin{array}{c}0.026 \\
{[0.022]}\end{array}$ & $\begin{array}{r}-0.002 \\
{[0.061]}\end{array}$ \\
\hline Terms of trade & $\begin{array}{c}-0.004 \\
{[0.007]}\end{array}$ & $\begin{array}{c}0.009 \\
{[0.012]}\end{array}$ & $\begin{array}{c}-0.020 \\
{[0.042]}\end{array}$ & $\begin{array}{c}-0.028 \\
{[0.019]}\end{array}$ & $\begin{array}{r}-0.082 \\
{[0.121]}\end{array}$ \\
\hline FDIs & $\begin{array}{l}0.179 * * \\
{[0.081]}\end{array}$ & $\begin{array}{c}0.204 * \\
{[0.106]}\end{array}$ & $\begin{array}{c}0.531 * \\
{[0.316]}\end{array}$ & $\begin{array}{l}0.488^{* * * *} \\
{[0.127]}\end{array}$ & $\begin{array}{c}0.291 \\
{[0.372]}\end{array}$ \\
\hline Public social spending & $\begin{array}{l}0.199 * * \\
{[0.094]}\end{array}$ & $\begin{array}{c}0.091 \\
{[0.130]}\end{array}$ & $\begin{array}{c}-0.946 * \\
{[0.571]}\end{array}$ & $\begin{array}{c}-0.172 \\
{[0.199]}\end{array}$ & $\begin{array}{c}-0.504 \\
{[0.653]}\end{array}$ \\
\hline Variation of years of education & $\begin{array}{c}1.485 \\
{[1.050]}\end{array}$ & $\begin{array}{c}3.104 \\
{[2.026]}\end{array}$ & $\begin{array}{c}5.437 \\
{[4.004]}\end{array}$ & $\begin{array}{c}2.356 \\
{[1.477]}\end{array}$ & $\begin{array}{c}4.628 \\
{[4.593]}\end{array}$ \\
\hline Constant & $\begin{array}{l}61.981 * * * \\
{[2.032]}\end{array}$ & $\begin{array}{l}54.821 * * * \\
{[2.497]}\end{array}$ & $\begin{array}{l}78.509 * * * \\
{[14.238]}\end{array}$ & $\begin{array}{l}75.733 * * * \\
{[6.392]}\end{array}$ & $\begin{array}{l}110.272 * \\
{[58.274]}\end{array}$ \\
\hline Country dummies & yes & yes & yes & yes & yes \\
\hline Observations & 339 & 325 & 284 & 323 & 303 \\
\hline Endogeneity test & 0.002 & 0.000 & 0.000 & 0.000 & 0.000 \\
\hline$R$-squared & 0.755 & 0.544 & -1.925 & 0.014 & -4.185 \\
\hline
\end{tabular}

Source: Author's compilation.

$* * * P<0.01$.

$* * P<0.05$.

$* P<0.1$.

Robust standard errors in brackets.

FDI, foreign direct investment; GDP, gross domestic product; REER, real effective exchange rate.

more equally distributed among taxpayers (Duncan \& Sabirianova Peter, 2016). Therefore, the main regressor in the baseline specification is replaced with a number of indicators such as the share of direct taxes on GDP (Table 4, model 2), ${ }^{9}$ the share of direct taxes on indirect taxes (Table 4 , model 3$)^{10}$ and the contribution of direct taxes on total tax revenue (Table 4, model 4). Tax coefficients are negative and statistically significant across all specifications confirming that the recent changes in tax composition

\footnotetext{
${ }^{9}$ Direct taxes also include resource and non-resource components but exclude social contributions. Only in the case of Argentina, information refers to the non-resource component.

${ }^{10}$ Although indirect taxes do not have a direct effect on disposable income, the share of direct taxes on indirect taxes is considered as a good proxy of the progressivity of tax system (Cornia et al., 2011).
} 
Table 5. Regression results, taxation and inequality in Latin American countries, 1990-2015 (alternative dependent variables)

\begin{tabular}{lccccc}
\hline & Gini & Palma ratio & p95_p50 & p95_p80 & p90_p10 \\
\hline Tax/GDP & $-0.844^{* * *}$ & $-0.150^{* * *}$ & $-0.086^{* * *}$ & $-0.025^{* * * *}$ & $-0.853^{* * * *}$ \\
& {$[0.155]$} & {$[0.029]$} & {$[0.021]$} & {$[0.005]$} & {$[0.194]$} \\
GDP per capita & $-0.380^{* *}$ & $-0.107^{* * *}$ & $-0.077^{* * *}$ & -0.004 & $-0.453^{* * *}$ \\
& {$[0.156]$} & {$[0.038]$} & {$[0.027]$} & {$[0.006]$} & {$[0.231]$} \\
REER & $-0.018^{* *}$ & $-0.004^{* *}$ & -0.002 & -0.000 & $-0.018^{* *}$ \\
& {$[0.008]$} & {$[0.002]$} & {$[0.001]$} & {$[0.000]$} & {$[0.009]$} \\
Debt/GDP & $0.028^{* * *}$ & $0.007^{* * *}$ & $0.006^{* * *}$ & $0.001^{* * *}$ & $0.023^{* *}$ \\
& {$[0.009]$} & {$[0.002]$} & {$[0.001]$} & {$[0.000]$} & {$[0.010]$} \\
Terms of trade & -0.004 & -0.002 & $-0.004^{* *}$ & $-0.001^{* * *}$ & 0.015 \\
& {$[0.007]$} & {$[0.002]$} & {$[0.001]$} & {$[0.000]$} & {$[0.012]$} \\
FDIs & $0.179^{* *}$ & $0.075^{* * *}$ & $0.044^{* * *}$ & $0.009^{* * *}$ & $0.506^{* * *}$ \\
& {$[0.081]$} & {$[0.023]$} & {$[0.015]$} & {$[0.003]$} & {$[0.176]$} \\
Public social spending & $0.199^{* *}$ & $0.050^{*}$ & 0.020 & 0.002 & $0.434^{*}$ \\
& {$[0.094]$} & {$[0.030]$} & {$[0.016]$} & {$[0.004]$} & {$[0.241]$} \\
Variation of years of education & 1.485 & 0.105 & 0.194 & $0.060^{*}$ & 0.242 \\
& {$[1.050]$} & {$[0.181]$} & {$[0.122]$} & {$[0.034]$} & {$[1.307]$} \\
Constant & $61.981^{* * *}$ & $5.833^{* * *}$ & $6.070^{* * *}$ & $2.429^{* * *}$ & $22.506^{* * *}$ \\
& {$[2.032]$} & {$[0.413]$} & {$[0.338]$} & {$[0.083]$} & {$[2.413]$} \\
Country dummies & yes & yes & yes & yes & yes \\
Observations & 339 & 256 & 256 & 256 & 256 \\
Endogeneity test & 0.002 & 0.074 & 0.261 & 0.192 & 0.137 \\
$R$-squared & 0.755 & 0.790 & 0.788 & 0.820 & 0.679 \\
\hline
\end{tabular}

Source: Author's compilation.

$* * * P<0.01$.

$* * P<0.05$.

$* P<0.1$.

Robust standard errors in brackets.

FDI, foreign direct investment; GDP, gross domestic product; REER, real effective exchange rate.

played a key role in reducing inequality in Latin America over the period 1990-2015. Table 4 also provides more detailed analysis on the impact of different types of direct taxes (model 5). In particular, the share of direct taxes on total revenue is split into the share of taxes on income, profits and capital gains on total tax revenue and on the share of property taxes on total tax revenue. ${ }^{11}$ The coefficient of taxes on income, profits and capital gains is negative and statistically significant at 10 per cent while that on property taxes is not statistically significant. Summing up, these results confirm that the increasing contribution of direct taxes has promoted the progressivity and redistributivity of taxation in Latin America.

\subsection{Tax Effects on the Different Parts of the Distribution}

Previous studies focus only on aggregate income Gini coefficient. Nevertheless, this could mask important information. To overcome this problem, the present study replaces the Gini index with a number of indicators such as the Palma ratio, which is the ratio of the

\footnotetext{
${ }^{11}$ Unfortunately, it is not possible to distributional consequences of taxation relying on a deeper tax disaggregation because data on personal or corporate income are missing in many cases.
} 
income share of the top 10 per cent to that of the bottom 40 per cent (Cobham \& Sumner, 2013) as well as the $90 / 10$, the $95 / 50$ and the $95 / 80$ percentile ratios. ${ }^{12}$

Table 5 summarizes the results. The sign and statistical significance of the coefficients shown across all the specifications are similar to those reported in the baseline specification. However, it is interesting to observe that taxation seems less able to influence disparities in the top of the distribution. In particular, an increase on these taxes would slightly reduce the distance between the 95th and the 80th percentile (Table 5, column 5) while it appears more effective in reducing the gap between the top and the bottom of the distribution (i.e. the 90/10 percentile ratio decreases) (Table 5, column 6) and the gap between the top and the middle of the distribution (i.e. the 95/50 percentile ratio decreases) (Table 5, column 4). Overall, results of this study confirm that taxation influences income distribution, reducing the distance between the lower and the middle class to the upper class. Yet it also confirms that the low effectiveness of taxation in promoting equality is most probably due to the inability of governments to tax top incomes (Amarante \& Jiménez, 2016).

\section{CONCLUSIONS}

This paper confirms that the recent changes in taxation have influenced the evolution of inequality in Latin America during the last two decades. In particular, it shows that both tax level and tax composition matter. Tax revenue increased since the 1990s and especially during the 2000s. However, tax changes in the first period were mainly driven by the rise in taxes sales and more specifically by the notable growth recorded by VAT. In contrast, the increase in tax revenue in the second period was related to the performance recorded by taxes on income, profits and capital gains, which contributed to promoting progressivity and redistributivity of taxation in Latin American countries. Furthermore, this work provides some useful insights on the impact of taxation on different parts of the distribution. In particular, the analysis shows that income taxation influences the distribution mainly by reducing the distance between the middle class and the upper class. However, the effect is limited at the top of the distribution.

Overall, it is evident that the effectiveness of taxation in promoting equality in Latin America is still limited by several factors. The redistributive capacity of the tax system is small because of the inability of governments to mobilize tax revenue to increase the tax/GDP ratio to its potential. Cornia et al. (2011) estimate that, on average, the tax/GDP ratio could still be raised by near 4 points in the 2000s and even more excluding Argentina and Brazil as they have a tax/GDP ratio above the international norm. The relative contribution of indirect taxes is still high and reduces the progressivity of the tax system. In particular, around 2010, the share of taxes on sales on total tax revenue was around 40 per cent whereas it was less than 30 per cent in advanced economies. Although the significant growth recorded by taxes on incomes, profits and capital gains, the contribution of personal income taxes is still low (less than 2 per cent of GDP) owing to the tax rate structures, the narrow tax base, the high level of informality and tax evasions. Also the contribution of property taxes on total tax revenue is low and still limited by the weak administrative capacity of local governments, lack of regular update of cadastre values, property registers characterized by low coverage ratios as well as the historical ties

\footnotetext{
${ }^{12}$ These data are extracted from the Socio-Economic Database for Latin America and the Caribbean.
} 
between political and economic elites that have reduced the possibility to tax the richest groups.

To promote the redistributive role of taxation, Latin American governments should promote tax revenue mobilization balancing the contribution between direct and indirect taxes. In particular, there is some room to strengthen income taxation by increasing the effective top tax rates considering their current low level and the disproportionate share of income owned by top income earners. Among the recent examples of reform, the dual tax system represents one of the most interesting solutions. At the same time, it is necessary to highlight that taxing people is not a technocratic exercise. Governments should strengthen the fiscal pact with their citizens ensuring that the increases in taxes meet peoples' expectations in terms of the quantity and quality of public services.

\section{ACKNOWLEDGEMENTS}

The author would like to thank Tony Addison, Miguel Niño-Zarazúa, Pirttilä, Jukka and three anonymous reviewers for their helpful and constructive comments. The author also acknowledges with gratitude Giovanni Andrea Cornia and the participants at a workshop organized by the United Nations University World Institute for Development Economics Research (UNU-WIDER) in Helsinki (March 2016) for their comments and feedback on this paper. This paper was developed with support by UNU-WIDER.

\section{REFERENCES}

Amarante V, Jiménez JP. 2016. Income distribution and the imposition of high taxes in Latin America. Cuadernos de Economía 35(67): 39-73.

Arellano M, Bond S. 1991. Some tests of specification for panel data: Monte Carlo evidence and an application to employment equations. Review of Economic Studies 58: 277-297.

Aristy-Escuder J, Cabrera M, Moreno-Dodson B, Sánchez-Martín M. 2016. Fiscal policy and redistribution in the Dominican Republic. CEQ Working Paper 47, CEQ Institute, Tulane University.

Atkinson AB. 2015. Inequality: What Can Be Done? Harvard University Press: Cambridge, MA.

Atkinson AB, Leigh A. 2010. The distribution of top incomes in five Anglo-Saxon countries over the twentieth century. IZA Discussion Paper 4937, May.

Battistón D, García-Domench C, Gasparini L. 2014. Could an increase in education raise income inequality?: evidence for Latin America. Latin American Journal of Economics 51(1): 1-39.

Bird RM, Zolt EM. 2005. Rethinking redistribution: tax policy in an era of rising inequality. UCLA Law Review 52: 1627-1695.

Bird RM, Zolt EM. 2013. Taxation and inequality in the Americas: changing the fiscal contract?. International Center for Public Policy Working Paper Series, Paper 50. Atlanta, GA: Andrew Young School of Policy Studies, Georgia State University.

Blundell R, Bond S. 1998. Initial conditions and moment restrictions in dynamic panel data models. Journal of Econometrics 87: 115-143.

Burdín G, Esponda F, Vigorito A. 2014. Inequality and top incomes in Uruguay: a comparison between household surveys and income tax micro-data. CEQ Working Paper 21, CEQ Institute. 
Cano L. 2015. Personal income tax and income inequality. New evidence from a South American country: Ecuador 2007-2011. Rochester, NY: Social Science Research Network (SSRN).

CEDLAS and World Bank (n.d.). Socio-Economic Database for Latin America and Caribbean (SEDLAC). Available at: http://sedlac.econo.unlp.edu.ar/eng/ (accessed 2017).

Cobham A, Sumner A. 2013. Is It All About the Tails? The Palma Measure of Income Inequality. CGD Working Paper: Washington DC.

Cord L, Barriga-Cabanillas O, Lucchetti L, Rodríguez-Castelán C, Sousa LD, Valderrama D. 2016. Inequality stagnation in Latin America in the aftermath of the global financial crisis. Review of Development Economics 21: 157-181. https://doi.org/10.1111/rode.12260

Cornia GA (Ed). 2014. Falling Inequality in Latin America: Policy Changes and Lessons. Oxford University Press: Oxford.

Cornia GA, Martorano B. 2012. 'Development policies and income inequality in selected developing regions, 1980-2010'. UNCTAD Discussion Paper 210. Geneva, UNCTAD.

Cornia GA, Gómez-Sabaíni JC, Martorano B. 2011. A new fiscal pact, tax policy changes and income inequality. WIDER Working Paper 2011/70. Helsinki: UNU-WIDER.

Cruces G, Gasparini L. 2008. A distribution in motion: the case of Argentina. CEDLAS Working Paper 0078. Argentina: Center for Distributive, Labour and Social Studies (CEDLAS), Universidad Nacional de La Plata

Duncan D, Sabirianova Peter K. 2016. Unequal inequalities: do progressive taxes reduce income inequality? International Tax and Public Finance 23(4): 762-783.

ECLAC. 2013. Fiscal Panorama of Latin America and the Caribbean-Tax Reform and Renewal of the Fiscal Covenant. Economic Commission for Latin America and the Caribbean (ECLAC), United Nations: Santiago, Chile.

ECLAC. 2015. Panorama Fiscal de América Latina y el Caribe 2015: dilemas y espacios de politicas. Economic Commission for Latin America and the Caribbean (ECLAC), United Nations: Santiago, Chile.

ECLAC. 2016. Panorama Fiscal de América Latina y el Caribe 2016: las finanzas públicas ante el desafio de conciliar austeridad con crecimiento e igualdad. Economic Commission for Latin America and the Caribbean (ECLAC), United Nations: Santiago, Chile.

ECLAC and IEF. 2014. Los efectos de la política fiscal sobre la redistribución en América Latina y la Unión Europea. Colección Estudios N ${ }^{\circ} 8$ (Serie Estados de la Cuestión). Madrid, EUROsociALFIIAPP.

Edwards S, Esquivel G, Márquez G (Eds). 2007. The Decline of Latin American Economies: Growth, Institutions, and Crises. University of Chicago Press: Chicago.

Engerman SL, Sokoloff KL. 2005. Colonialism, inequality, and long-run paths of development. NBER Working Paper Series 11057. Cambridge, MA: National Bureau of Economic Research (NBER).

Epple D, Romano RE. 1996. Ends against the middle: determining public service provision when there are private alternatives. Journal of Public Economics. 62: 297-325.

Feldstein M. 2012. The Mirrlees Review. Journal of Economic Literature 50(3): 781-790.

Fricke H, Süssmuth D. 2014. Growth and volatility of tax revenues in Latin America. World Development 54(C): 114-138.

Gómez-Sabaíni JC, Morán D. 2014. Tax policy in Latin America: assessment and guidelines for a second generation of reforms. Macroeconomics of Development Series 133. Santiago, Chile: Economic Commission for Latin America and the Caribbean, United Nations.

Gómez-Sabaíni JC, Martorano B, Morán D. 2016. Taxation and Inequality: Lessons from Latin America. World Social Science Report on Inequality. UNESCO: Paris. 
Goñi E, Lopéz J, Servén L. 2011. Fiscal redistribution and income inequality in Latin America. World Development 39(9): 1558-1569.

Helleiner G. 2011. Trade, exchange rates and global poverty: policies for the poorest. Paper presented at the IDS Conference in honour of Sir Richard Jolly, 17-19 November. Brighton: Institute of Development Studies.

Instituto Centroamericano de Estudios Fiscales (ICEFI). 2017a. Incidencia de la Politica Fiscal en la Desigualdad y la Pobreza en El Salvador. CEQ Working Paper 49, CEQ Institute, Tulane University.

Instituto Centroamericano de Estudios Fiscales (ICEFI). 2017b. Incidencia de la Politica Fiscal en la Desigualdad y la Pobreza en Guatemala. CEQ Working Paper 50, CEQ Institute, Tulane University.

Kaldor N. 1963. Will underdeveloped countries learn to tax? Foreign Affairs 41: 410-419.

Lee Y, Gordon RH. 2005. Tax structure and economic growth. Journal of Public Economics 89(5-6): 1027-1043.

Lewbel A. 2012. Using heteroscedasticity to identify and estimate mismeasured and endogenous regressor models. Journal of Business \& Economic Statistics 30(1): 67-80.

López-Calva LF, Lustig N. 2010. Declining Inequality in Latin America: A Decade of Progress? Brookings Institution Press and UNDP: Washington, DC, and New York.

Lustig N. 2013. Latin America's inequality success story. Current History 112(751): 64.

Lustig N. 2016. El impacto del sistema tributario y el gasto social en la distribución del ingreso y la pobreza en América Latina: Bolivia, Brasil, Chile, Colombia, Costa Rica, Ecuador, El Salvador, Guatemala, México, Perú y Uruguay. CEQ Working Paper 37. Uruguay: Commitment to Equity (CEQ) Institute.

Mahon J. 2009. Tax reforms and income distribution in Latin America, Prepared for delivery at the XXVIII Congress of the Latin American Studies Association, Rio de Janeiro, 11-14 June 2009.

Martínez-Vázquez J, Vulovic V, Moreno-Dodson B. 2012. The impact of tax and expenditure policies on income distribution: evidence from a large panel of countries. Hacienda Pública Española 200(1): 95-130.

Martorano B. 2014. The impact of Uruguay's 2007 tax reform on equity and efficiency. Development Policy Review 32(6): 701-714.

Martorano B, Cornia GA. 2011. The IDLA dataset: a tool to analyze recent changes in income inequality in L.AA. Available at: https://www.wider.unu.edu/database/income-distribution-latinamerica

Meltzer A, Richard S. 1981. A rational theory of the size of government. Journal of Political Economy 89(5): 914-927.

Musgrave R. 1959. The Theory of Public Finance. McGraw Hill: New York.

Piketty T. 2014. Capital in the Twenty First Century. Harvard University Press: Cambridge, MA.

Prichard W, Cobham A, Goodall A. 2014. The ICTD Government Revenue Dataset. ICTD Working Paper 19. Brighton: International Centre for Tax and Development (ICTD).

Rossignolo D. 2016. Taxes, expenditures, poverty and income distribution in Argentina. CEQ Working Paper 45. Uruguay: Commitment to Equity (CEQ) Institute, Tulane University.

Székely M, Mendoza P. 2015. Is the decline in inequality in Latin America here to stay? Journal of Human Development and Capabilities 16(3): 397-419.

Tsounta E, Osueke A. 2014. What is behind Latin America's declining income inequality?. IMF Working Paper WP/14/124. Washington, DC: International Monetary Fund (IMF).

World Bank. 2011. A break with history: fifteen years of inequality reduction in Latin America. In LCSPP Poverty and Labor Brief 2. World Bank: Washington, DC. 


\section{SUPPORTING INFORMATION}

Additional Supporting Information may be found online in the supporting information tab for this article. 